\title{
Simultaneous Aseptic Meningitis and Acute Non-Mumps Associated Parotitis
}

\author{
Hoon Oh ${ }^{1}$; Hoon Shik Yang ${ }^{1}$; Kyung Soo Kim ${ }^{1, *}$ \\ ${ }^{1}$ Department of Otorhinolaryngology-Head and Neck Surgery, College of Medicine, Chung-Ang University, Seoul, Korea \\ *Corresponding author: Kyung Soo Kim, Department of Otorhinolaryngology-Head and Neck Surgery, College of Medicine, Chung-Ang University, Seoul, Korea. Postal Code: 156-755. \\ Tel:+82-262991765, Fax:+82-28251765, E-mail: 99-21045@hanmail.net
}

Received: May 12, 2013; Revised: June 9, 2013; Accepted: August 21, 2013

\begin{abstract}
Introduction: The classic "Mumps" is known as a viral parotitis caused by mumps virus belonging to the genus Rubulavirus in the Paramyxoviridae family.

Case Presentation: We reviewed three patients diagnosed with aseptic meningitis due to acute non-mumps associated parotitis based on clinical and laboratory findings. While there are many similarities between the clinical characteristics of classic mumps and acute non-mumps associated parotitis, some significant differences exist. In addition, there are some important differences between mumps meningitis and aseptic meningitis due to non-mumps associated parotitis. If acute parotitis accompanies with clinical manifestations different from classic mumps and associated with aseptic meningitis in early stage of the disease with initially negative serological test for mumps, acute parotitis with aseptic meningitis caused by non-mumps virus should be considered and various serological tests should be performed to identify the causative virus.

Discussion: PCR or enzyme linked immunosorbent assay (ELISA) on serum or cerebrospinal fluid would be the inevitable basis for accurate diagnosis in such cases.
\end{abstract}

Keywords: Mumps; Meningitis, Aseptic; Parotitis

\section{Introduction}

The classic "Mumps" is known as a viral parotitis caused by mumps virus belonging to the genus Rubulavirus in the Paramyxoviridae family $(1,2)$, but various viral pathogens have been identified as causes of acute viral infection of the salivary glands (1). These include viruses such as parainfluenza (types 1, 2 and 3) virus, Influenza, Coxsackie virus, ECHO (enteric cytopathic human orphan) virus and Lymphocytic choriomeningitis virus (3-6). Moreover, cytomegalovirus and adenovirus have been reported as causative pathogens of acute parotitis in patients with AIDS. Direct HIV (human immunodeficiency virus) infection of the parotid glands is rare, but is characterized by chronic, cystic parotid enlargement (7-9).

Complications regarding classic mumps syndrome have been widely known such as orchitis, oophoritis, mastitis, sensorineural hearing loss, pancreatitis, aseptic meningitis and encephalitis. Of these complications, aseptic meningitis is the most common neurologic manifestation which occurs in $1-10 \%$ of patients infected with mumps (10). On the other hand, other viruses responsible for acute parotitis are less common, and understanding of their associated complications is more limited.
Herein we reported three pediatric patients with clinical manifestations of aseptic meningitis as a complication of non-mumps associated parotitis and compared its differences with classic forms of aseptic meningitis caused by classic mumps.

\section{Cases Presentation}

All of three cases were referred to our department between January 2005 and December 2009, with conclusively diagnosis of "secondary aseptic meningitis due to acute non-mumps associated parotitis" based on the clinical and laboratory findings. All of three cases were male with ages ranging from 16 to 17 years. The characteristics of individual cases are given in Table 1 . There were no prodromal symptoms including headache, myalgias, arthralgias, anorexia and malaise prior to the development of parotitis. The initial symptoms were unilateral parotid gland swelling, headache and high fever up to $39.2 \sim 39.3^{\circ} \mathrm{C}$ in three cases respectively. All of them were in the left parotid gland and had headache and fever at the same time in parotid swelling. All of them had an alert mental state with no meningeal irritation signs in physical examination. All of them responded to conserva-

Implication for health policy/practice/research/medical education:

If acute parotitis accompanies with clinical manifestations different from classic mumps and associated with aseptic meningitis in early stage of the disease with initially negative serological test for mumps, acute parotitis with aseptic meningitis caused by non-mumps virus should be considered and various serological tests should be performed to identify the causative virus.

Copyright (C) 2013, Infectious Diseases and Tropical Medicine Research Center; Published by Kowsar Corp. This is an open-access article distributed under the terms of the Creative Commons Attribution License, which permits unrestricted use, distribution, and reproduction in any medium, provided the original work is properly cited. 
Kim KS et al.

tive management and showed recovery without sequelae within 11 days. On computed tomography, the left parotid gland was diffusely enlarged with a moderate enhancement, also several enlarged lymph nodes were found in the left internal jugular chain in all cases.

On laboratory tests, serum markers for Mumps-IgM had negative results, but serum markers for Mumps-IgG had positive findings. Serum markers for herpes simplex virus (HSV), cytomegalovirus (CMV), varicella-zoster virus $(\mathrm{VZV})$ and Epstein-Barr virus (EBV) had negative results.
The highest levels of serum amylase were found in all cases at initial work-up (Table 2). On the second day of hospitalization, spinal tapping was performed in all cases. Analysis of cerebrospinal fluid (CSF) was shown in the Table 3. Chemical analysis and cytology of CSF supported the diagnosis of viral meningitis. However, all virological examinations of CSF had negative results (Table 2). Furthermore, 1 week later, follow-up serologic tests for Mumps-IgM had negative findings.

\begin{tabular}{|c|c|c|c|c|c|c|c|c|}
\hline Patient & Age/Sex & $\begin{array}{c}\text { Chief Com- } \\
\text { plaint }\end{array}$ & Onset & Location & $\begin{array}{l}\text { Associated } \\
\text { Symptoms }\end{array}$ & $\begin{array}{l}\text { Meningeal Ir- } \\
\text { ritation Signs }\end{array}$ & $\begin{array}{c}\text { Computed Tomographic } \\
\text { Findings }\end{array}$ & Discharge \\
\hline 1 & $16 / \mathrm{M}$ & $\begin{array}{c}\text { Neck swelling } \\
\text { left }\end{array}$ & 1 day ago & $\begin{array}{l}\text { Left } \\
\text { parotid } \\
\text { gland }\end{array}$ & $\begin{array}{l}\text { Headache } \\
\text { Fever up to } \\
39.2^{\circ} \mathrm{C}\end{array}$ & Negative & $\begin{array}{l}\text { Diffusely enlarged and mod- } \\
\text { erately enhanced left parotid } \\
\text { gland, diffuse soft tissue fat } \\
\text { infiltration in left cheek, and } \\
\text { neck, several enlarged lymph } \\
\text { nodes in the left internal jugu- } \\
\text { lar chain }\end{array}$ & $\begin{array}{l}\text { Hospital } \\
\text { day } 11\end{array}$ \\
\hline 2 & $17 / \mathrm{M}$ & $\begin{array}{c}\text { Neck swelling } \\
\text { left }\end{array}$ & 2 days ago & $\begin{array}{l}\text { Left } \\
\text { parotid } \\
\text { gland }\end{array}$ & $\begin{array}{l}\text { Headache } \\
\text { Fever up } \\
\text { to } 39.3^{\circ} \mathrm{C} \text {, } \\
\text { nausea, } \\
\text { vomiting, } \\
\text { alert mental } \\
\text { status }\end{array}$ & Negative & $\begin{array}{l}\text { Diffusely enlarged left parotid } \\
\text { gland, several enlarged lymph } \\
\text { nodes in the left internal jugu- } \\
\text { lar chain }\end{array}$ & $\begin{array}{l}\text { Hospital } \\
\text { day } 11\end{array}$ \\
\hline 3 & $17 / \mathrm{M}$ & $\begin{array}{c}\text { Neck swelling } \\
\text { left }\end{array}$ & 2 days ago & $\begin{array}{l}\text { Left } \\
\text { parotid } \\
\text { gland }\end{array}$ & $\begin{array}{l}\text { Headache, } \\
\text { Fever up } \\
\text { to } 39.2^{\circ} \mathrm{C}, \\
\text { alert mental } \\
\text { status }\end{array}$ & Negative & $\begin{array}{l}\text { Diffusely enlarged left parotid } \\
\text { gland, several enlarged lymph } \\
\text { nodes in the left jugular chain }\end{array}$ & $\begin{array}{l}\text { Hospital } \\
\text { day } 10\end{array}$ \\
\hline
\end{tabular}

Table 2. Laboratory Test Results ${ }^{\mathrm{a}}$

\begin{tabular}{|c|c|c|c|c|c|c|c|c|c|c|c|}
\hline \multirow[t]{2}{*}{ Patient(Serum) } & \multirow[t]{2}{*}{ Amylase (Highest), IU/L } & \multicolumn{2}{|c|}{ Mumps } & \multicolumn{2}{|c|}{ HSV } & \multicolumn{2}{|c|}{ CMV } & \multicolumn{2}{|c|}{ VZV } & \multicolumn{2}{|c|}{ EBV } \\
\hline & & IgM & IgG & IgM & IgG & IgM & IgG & IgM & IgG & IgM & IgG \\
\hline $\mathbf{1}$ & 935 & $\mathrm{~N}$ & $\mathrm{P}$ & $\mathrm{N}$ & $\mathrm{N}$ & $\mathrm{N}$ & $\mathrm{N}$ & $\mathrm{N}$ & $\mathrm{N}$ & $\mathrm{N}$ & $\mathrm{N}$ \\
\hline 2 & 465 & $\mathrm{~N}$ & $\mathrm{P}$ & $\mathrm{N}$ & $\mathrm{N}$ & $\mathrm{N}$ & $\mathrm{N}$ & $\mathrm{N}$ & $\mathrm{N}$ & $\mathrm{N}$ & $\mathrm{N}$ \\
\hline 3 & 738 & $\mathrm{~N}$ & $P$ & $\mathrm{~N}$ & $\mathrm{~N}$ & $\mathrm{~N}$ & $\mathrm{~N}$ & $\mathrm{~N}$ & $\mathrm{~N}$ & $\mathrm{~N}$ & $\mathrm{~N}$ \\
\hline
\end{tabular}

Table 3. Cerebrospinal Fluid Analysis ${ }^{\mathrm{a}}$

\begin{tabular}{|c|c|c|c|c|c|c|c|c|c|c|c|c|c|c|c|}
\hline 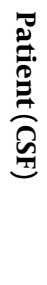 & 롶 & $\tilde{a}$ & 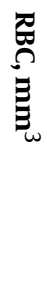 & 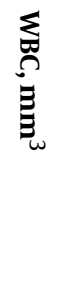 & do & 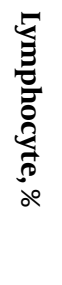 & 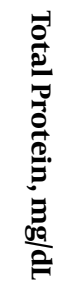 & 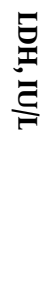 & 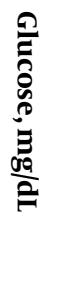 & 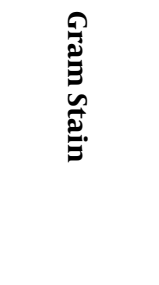 & 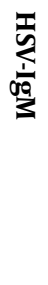 & $\underset{\frac{1}{60}}{3}$ & 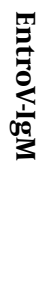 & $\underset{\nabla}{\overline{7}}$ & $\underset{\Xi}{\underline{\Omega}}$ \\
\hline $\mathbf{1}$ & 6.6 & 1.006 & 40 & 845 & 0 & 100 & 105.8 & 22 & 45 & No bacteria & $\mathrm{N}$ & $\mathrm{N}$ & $\mathrm{N}$ & $\mathrm{N}$ & $\mathrm{N}$ \\
\hline 2 & 7.2 & 1.006 & 8 & 438 & 2 & 98 & 55.3 & 119 & 59 & No bacteria & $\mathrm{N}$ & $\mathrm{N}$ & $\mathrm{N}$ & $\mathrm{N}$ & $\mathrm{N}$ \\
\hline 3 & 6.8 & 1.006 & 10 & 680 & 0 & 100 & 103.1 & 30 & 54 & No bacteria & $\mathrm{N}$ & $\mathrm{N}$ & $\mathrm{N}$ & $\mathrm{N}$ & $\mathrm{N}$ \\
\hline
\end{tabular}

a Abbreviations: CSF, cerebrospinal fluid; EntorV, enterovirus; LDH, lactate dehydrogenase; SG, specific gravity; RBC, red blood cell, TPHA, Treponema pallidum hemagglutination test; VDRL, venereal disease research laboratory test; WBC, white blood cell. 
Oh Het al.

\section{Discussion}

Mumps virus can be easily detected from saliva, cerebrospinal fluid, urine, or seminal fluid within the first week of parotitis onset $(11,12)$. If viral detection fails, a definitive diagnosis can be performed by serological markers. Serological confirmative diagnosis is mainly based on detection of virus-specific IgM and IgG antibodies, measured by direct or indirect ELISA (13). In our case series, serological tests showed that IgM testing with appropriately timed serum samples had negative result and IgG testing had positive result in all cases. Therefore, the serological results are consistent with a past mumps infection , prior vaccination, and the late stage of active infection. However, they all had no prior infection history. On the contrary, because the mumps vaccination was included in the national immunization program (NIP) in 1985, and a booster dosage was given from 1997 in Korea (14), they all had previous measles, mumps, rubella (MMR) vaccination history. Therefore, we did not consider mumps virus as the causative agent of acute parotitis in our case series and additional viral serological tests to seek the causative agent, but all tests showed negative results.

Acute non-mumps associated parotitis caused by parainfluenza viruses or non-paramyxoviruses has a low incidence rate and therefore its clinical characteristics and complications including aseptic meningitis have rarely been reported. Of the non-mumps viruses mentioned earlier, parainfluenza virus (types 2 and 3) has been the only virus reported representing acute parotitis and aseptic meningitis simultaneously $(4,6,10,15,16)$. While there are some similarities between the clinical characteristics of classic mumps and non-mumps associated parotitis, some significant differences exist. First of all, approximately two thirds of patients have short prodromal symptoms before the development of parotitis presenting low-grade fever, headache, myalgias, arthralgias, anorexia, and malaise in classic mumps (13). However, there were no recognized prodromal symptoms in all 3 cases. Second, in classic mumps, swelling occurs in both parotid glands in $90 \%$ of cases. Glandular swelling generally begins on one side, followed by contralateral involvement within 1 to 5 days (13). However, only unilateral swelling of the parotid gland was found in our cases. Third, in classic mumps, $85 \%$ of patients occur in children younger than 15 years, but all of our patients were over 16 (5). Non-mumps associated parotitis has a rather high developmental age involving older children.

Aseptic meningitis due to mumps infection is the most common extrasalivary manifestation which is a benign entity without essential risk of mortality or long-term sequelae (13). Typical symptoms include high fever, headache, vomiting, neck stiffness, and lethargy (17). The diagnosis of CNS complications is relatively easy if there is salivary gland involvement, but in up to $50 \%$ of cases without salivary gland involvement, an accurate diagno- sis can be made only by serologic tests $(18,19)$. Furthermore, in patients with mumps meningitis, virus-specific IgM and IgG can be detected in CSF study (20). In our case series, there are some similar characteristics with classic mumps meningitis. First, aseptic meningitis occurred only in male patients. Second, our patients admitted with high fever and headache lasting for $72 \sim 96$ hours. Third, aseptic meningitis was a self-limited disease which showed spontaneous recovery without sequelae within 7 to 10 days with conservative management. However, there are following important differences. First, there is difference in the developmental stage of meningitis. In cases of aseptic meningitis due to mumps, it can manifest about 5 days after the onset of mumps parotitis or it can precede mumps parotitis by a week (21). However, in our case, aseptic meningitis occurred with the onset of parotitis. Second, in meningitis due to mumps, meningeal irritation signs were reported in $43-93 \%$ of cases (17) and appear much higher in older children, adolescents, and adults, but all of our patients showed negative MIS signs in physical examination. Third, in aseptic meningitis due to mumps, it occurs without salivary gland involvement in $50 \%$ of cases, but all of our patients showed unilateral parotid gland involvement.

We presented three patients as non-mumps associated parotitis with aseptic meningitis. Rubulavirus could not be identified as the causative pathogen (serial serum Anti-Mumps-IgM negative); all patients had positive titers for Anti-Mumps IgG indicative of a past infection or immunization. Moreover, serology study for HSV, CMV, VZV, and EBV had negative findings. However, in the reported patients, important additional viral testing was not performed. First, testing for mumps virus by PCR (polymerase chain reaction) from serum and CSF was not performed. Furthermore, an early infection might have potentially been missed. Second, we discussed parainfluenza virus, influenza virus, coxsackie virus, echovirus and lymphocytic choriomeningitis virus as possible causative pathogens of salivary gland infections. However, except serology for enterovirus, testing for these pathogens (serology, PCR) was not performed. Furthermore, lack of this data leaves the cause of diseases unresolved.

If acute parotitis accompanies with clinical manifestations different from classic mumps and associated with aseptic meningitis in early stage of the disease with initially negative serological test for mumps, acute parotitis with aseptic meningitis caused by non-mumps virus should be considered and various serological tests should be performed to identify the causative virus. Proper testing for the most likely causative pathogens including PCR or ELISA on serum or CSF would be inevitable to accurate diagnosis.

\section{Acknowledgements}

There was no acknowledgment. 
Kim KS et al.

\section{Authors' Contributions}

Study concept and design: Kyung Soo Kim; acquisition of data: Hoon Oh; analysis and interpretation of data: Hoon Oh; drafting of the manuscript: Hoon Oh; critical revision of the manuscript for important intellectual content: Hoon Shik Yang; statistical analysis: Kyung Soo Kim; administrative, technical, and material support: Kyung Soo Kim; study supervision: Kyung Soo Kim.

\section{Financial Disclosure}

We had no financial interests related to the materials in the manuscript.

\section{Funding/Support}

We had no funding or support related to the materials in the manuscript.

\section{References}

1. Bradley PJ. Microbiology and management of sialadenitis. Curr Infect Dis Rep. 2002;4(3):217-24.

2. Santak M, Kosutic-Gulija T, Tesovic G, Ljubin-Sternak S, GjeneroMargan I, Betica-Radic L, et al. Mumps virus strains isolated in Croatia in 1998 and 2005: Genotyping and putative antigenic relatedness to vaccine strains. J Med Virol. 2006;78(5):638-43.

3. Brill SJ, Gilfillan RF. Acute parotitis associated with influenza type A: a report of twelve cases. N Engl J Med.1977;296(24):1391-2.

4. Buckley JM, Poche P, McIntosh K. Parotitis and parainfluenza 3 virus. Am J Dis Child. 1972;124(5):789.

5. McAnally T. Parotitis: clinical presentations and management. Postgrad Med.1982;71(2):87-93.

6. Jantausch BA, Wiedermann BL, Jeffries B. Parainfluenza virus type 2 meningitis and parotitis in an 11-year-old child. South Med J.1995;88(2):230-1.
7. Redleaf MI, Bauer CA, Robinson RA. Fine-needle detection of cytomegalovirus parotitis in a patient with acquired immunodeficiency syndrome. Arch Otolaryngol Head Neck Surg. 1994;120(4):414-6.

8. Gelfand MS, Cleveland KO, Lancaster D, Corbett CE, Florendo NT. Adenovirus parotitis in patients with AIDS. Clin Infect Dis. 1994;19(6):1045-8.

9. Hanekom WA, Chadwick EG, Yogev R. Pneumococcal parotitis in a human immunodeficiency virus-infected child. Pediatr Infect Dis J. 1995;14(12):1113-4

10. Arguedas A, Stutman HR, Blanding JG. Parainfluenza type 3 meningitis. Report of two cases and review of the literature. Clin Pediatr(Phila).1990;29(3):175-8.

11. Jalal H, Bahadur G, Knowles W, Jin L, Brink N. Mumps epididymoorchitis with prolonged detection of virus in semen and the development of anti-sperm antibodies. J Med Virol. 2004;73(1):147-50.

12. Baum SG, Litman N. Mumps virus. In: Mandell GL, Douglas RG Bennett JE editors. Principles and practices of infectious diseases. 5th ed; 2000. p. 1776-81.

13. Hviid A, Rubin S, Muhlemann K. Mumps. Lancet 2008;371(9616):932-44.

14. Choi KM. Reemergence of mumps. Korean $J$ Pediatr 2010;53(5):623-8.

15. Craver RD, Gohd RS, Sundin DR, Hierholzer JC. Isolation of parainfluenza virus type 3 from cerebrospinal fluid associated with aseptic meningitis. Am J Clin Pathol.1993;99(6):705-7.

16. Wong VK, Steinberg E, Warford A. Parainfluenza virus type 3 meningitis in an 11-month-old infant. Pediatr Infect Dis J.1988;7(4):300-1.

17. Levitt LP, Rich TA, Kinde SW, Lewis AL, Gates EH, Bond JO. Central nervous system mumps. A review of 64 cases. Neurology. 1970;20(8):829-34.

18. Kilham L. Mumps meningoencephalitis with and without parotitis. Am J Dis Child. 1949;78(3):324-33.

19. Murray HG, Field CM, McLeod WJ. Mumps meningoencephalitis BrMed J.1960;1(5189):1850-3.

20. Forsberg P, Fryden A, Link H, Orvell C. Viral IgM and IgG antibody synthesis within the central nervous system in mumps meningitis. Acta Neurol Scand.1986;73(4):372-80.

21. Johnstone JA, Ross CA, Dunn M. Meningitis and encephalitis associated with mumps infection. A 10-year survey. Arch Dis Child. 1972;47(254):647-51. 